\title{
Chapter 8. Domesticated and Commensal Mammals of Austronesia and Their Histories
}

\section{Colin P. Groves}

A discussion is here presented of the origins and histories of the main domestic and commensal mammals of the Austronesian world. Some, such as the water buffalo, the dog and a number of rodent species, were introduced from Mainland Asian sources. Others, such as Bali cattle and the Celebes pig, were domesticated locally in Indonesia.

\section{Introduction}

A variety of animal species have travelled with Austronesians on their migrations through Southeast Asia, and some have gone further into the Pacific. In this paper I will discuss the ecology of some of these species, trying to understand their geographical distributions and the natures of their associations with Austronesian-speaking people. I will try also to identify the regions of their aboriginal wild distributions. In this way we can possibly make some statements about prehistoric Austronesian culture, subsistence and migration history.

\section{Partner in the Padi Fields: The Water-Buffalo}

Water-buffalo are so closely associated with wet rice cultivation that it is difficult to see how an efficient wet rice (sawah) economy could function without them. Their broad splaying hooves spread their weight out in swampy ground and they plod through the soft ricefields without sinking in as cattle would, hauling ploughs behind them and at the same time puddling the soil. If they need to spend long hours soaking in ponds or streams, that is a small price to pay for their services.

Asian buffaloes (Bubalus arnee), of which the water-buffalo is the domestic form, are restricted to floodplain and deltaic regions. Genuinely wild representatives still occur in Assam, especially along the Brahmaputra River; in the Mahanadi Delta extending inland to Bastar district; and on the borders of Nepal (Map 1). Until the turn of the century they also lived in the Sunderbans of Bengal, and the Mughal Emperors hunted them in the Indus Valley. Wild-living buffaloes in Sri Lanka, on the upper Chindwin, in the Chao Phraya Valley of Thailand and (until at least the 1920s) in the Irrawaddy Delta of Burma are also probably truly wild, although it remains possible that they may be feral. Those of Vietnam, Cambodia, Lampung, the Miri River in Sarawak and the 
Baluran National Park in Java are almost certainly feral; a wild buffalo was present in Java up to the early Holocene (remains occur in the Sampung Cave) but has since become locally extinct.

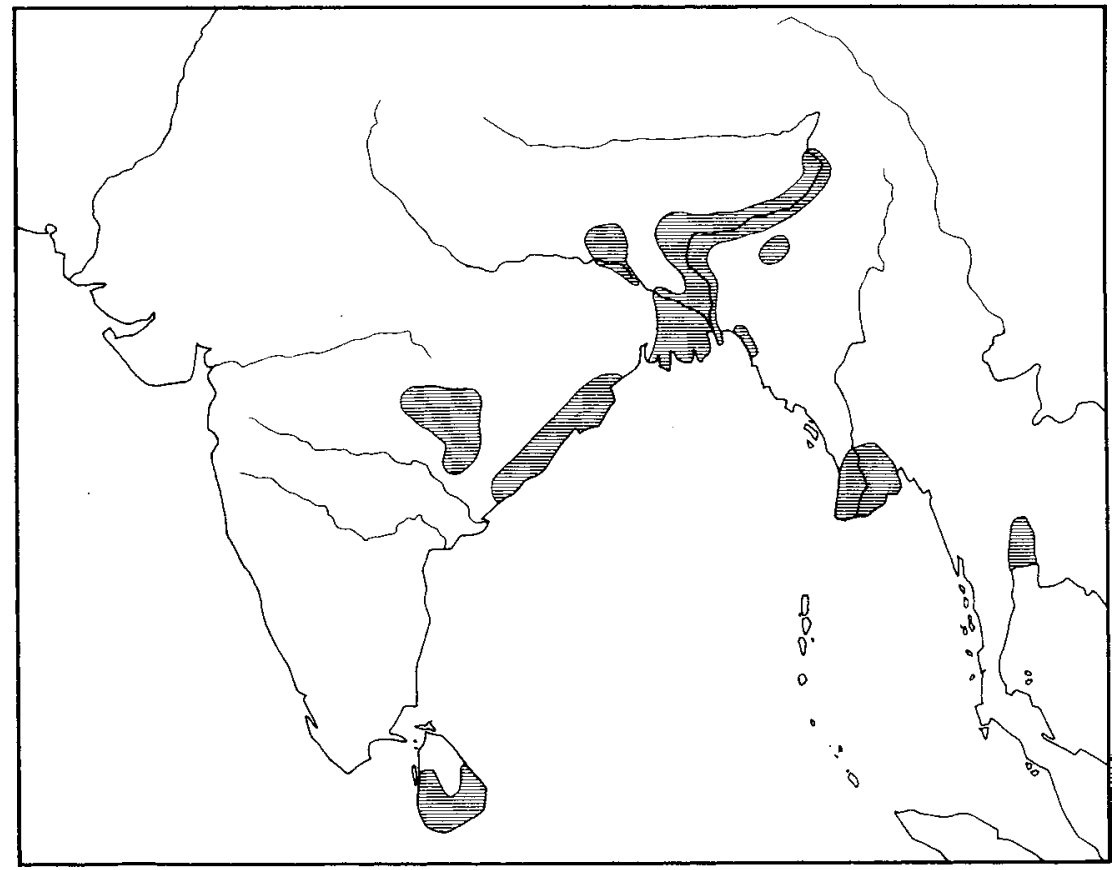

\section{Map 1. The distribution, within the past century, of wild Asian buffalo (Bubalus arnee).}

The distributional areas marked represent Sri Lanka, the Bastar region, Mahanadi Delta, southeast Nepal, Sunderbans, Brahmaputra Valley, upper Chindwin, Irrawaddy Delta, and Chao Phraya Valley. Evidence also suggests that wild buffalo existed in southern China within the last millennium.

Names available for subspecies of the wild Asian buffalo, if they should prove distinguishable, are:

Bubalus arnee arnee - Bengal

Bubalus arnee fulvus - Upper Assam

Bubalus arnee septentrionalis - Sunderbans

Bubalus arnee migona - Yala, Sri Lanka

Other populations which may be distinct are so far unnamed.

The name available for the domestic buffalo (water-buffalo) is Bubalus bubalis. It is not really, of course, a different species from the wild buffalo, but for a variety of reasons it seems useful to maintain the fiction that domestic species are different from their wild relatives/ancestors (Corbet and Clutton-Brock 1984). There are two general breed-groups of the domestic buffalo: swamp and river 
buffaloes (Mason 1974a). Swamp buffaloes are bred in Southeast Asia and China, northeastern India and also Sri Lanka. They are heavily built, with simple crescentic horns, and are grey with one or two white stripes on the throat, and white legs below the knees and hocks. They are indispensable for ploughing and other traction and their meat is eaten, but they give little or no milk.

River buffaloes, typical for the Indian subcontinent and parts of the Middle East and Europe, are longer-bodied and longer-legged than swamp buffaloes. The sacrum is more prominent than the withers, the horns curve back from a strongly convex forehead and are often tightly curled, and the colour is black, without white markings. There are numerous other consistent differences in conformation and in the skeleton between the two breed-groups; whether they truly prefer to bathe in swamps and rivers respectively I could not say. They also differ in chromosome number: swamp buffaloes have 48 chromosomes, river buffaloes 50 (Mason 1974b).

Swamp buffaloes differ little from each other wherever they live. Those of Sumba have exceptionally long, outswept horns. In Tanah Toraja, Sulawesi, they are very large and often piebald. In Thailand, Yunnan and South Sulawesi there are high frequencies of albinism. However, there are no true breeds. On the other hand, river buffaloes have given rise to a number of highly specialized breeds such as the Murrah, which is an excellent milker, and they have been exported to Egypt, Brazil and the West Indies. They are also replacing swamp buffaloes in parts of Thailand, Malaysia and the Philippines. The replacement by river buffaloes of the more primitive swamp type seems to have been going on for a long time; we not only have the oddity of the swamp type surviving in a peripheral region such as Sri Lanka, but the Toda buffaloes of the Nilgiri Hills are of swamp type, separated from the swamp buffaloes of Southeast Asia by most of the Indian subcontinent where only river buffaloes are used. Prehistoric depictions of domestic buffaloes with the characteristic crescentic horns of the swamp form are known from Mohenjo-Daro and from Ur, dating from the mid-third to early second millennia BC.

The wild Indian buffalo resembles an enormous version of the domestic swamp buffalo and is surely its direct ancestor, although its chromosomes are unknown. Mean skull lengths for different wild populations are as follows (in millimetres, followed by sample size in brackets):

\begin{tabular}{llll}
\hline & Male & Combined & Female \\
\hline Assam & $603(13)$ & & $585(12)$ \\
Bastar, Orissa & $574(2)$ & & $555(3)$ \\
Thailand & $556(5)$ & $545(8)$ \\
Nepal & & $557(4)$ & \\
Sri Lanka & & $539(6)$ & \\
\hline
\end{tabular}


In comparison, domestic buffaloes have skull lengths around 450-500 $\mathrm{mm}$, the river breeds tending to be smaller than most swamp buffaloes.

In order to get some idea of which wild population most resembled the domestic ones in skull form, and so forms the most suitable candidate for their ancestor (always assuming that river and swamp types do have a common domestic ancestor), I have undertaken a discriminant analysis on craniometric variables. The variables used were greatest skull length, biorbital breadth, postorbital breadth, occipital breadth (greatest), occipital breadth (constriction), breadth of horn base, nasal breadth posterior, nasal breadth anterior, nasal length, and basal skull length. It should be explained that not all measurements were available for every skull.

The results are shown in Figure 1. The first discriminant function (horizontal) accounts for 67.5 per cent of the total variance and is in part at least dependent on size, but also contrasts wide nasal tip with narrow nasal base and emphasizes relatively slender horn bases. The second function, which accounts for 14.6 per cent of total variance, contrasts a broad occipital constriction and broad nasals with a narrow postorbital constriction and short nasals. No other function accounted for more than 8 per cent of the total variance.

In Figure 1, means and one-standard-deviation circles have been plotted for all geographic samples, and individual specimens from other regions have been plotted separately. Assam, Nepal and Thailand are well separated from Bihar and the domestic samples, with individual specimens from central India (Bastar) and Sri Lanka falling between. The fact that the Bihar/Orissa sample (centring on the Mahanadi delta) is the only wild one whose dispersion widely overlaps that of the domestic samples suggests that, if skull form is any guide, this is the best bet for a wild ancestor. Did this important component of the wetrice complex come from that region of India? This would be surprising, given that this is well outside the Austronesian area and that the oldest putative domestic buffaloes come from Neolithic sites in southern China, although northeastern India is within the Austroasiatic (Munda-speaking) area. In what follows, we will see whether there is any analogy for such a distribution and inferred place of origin. 


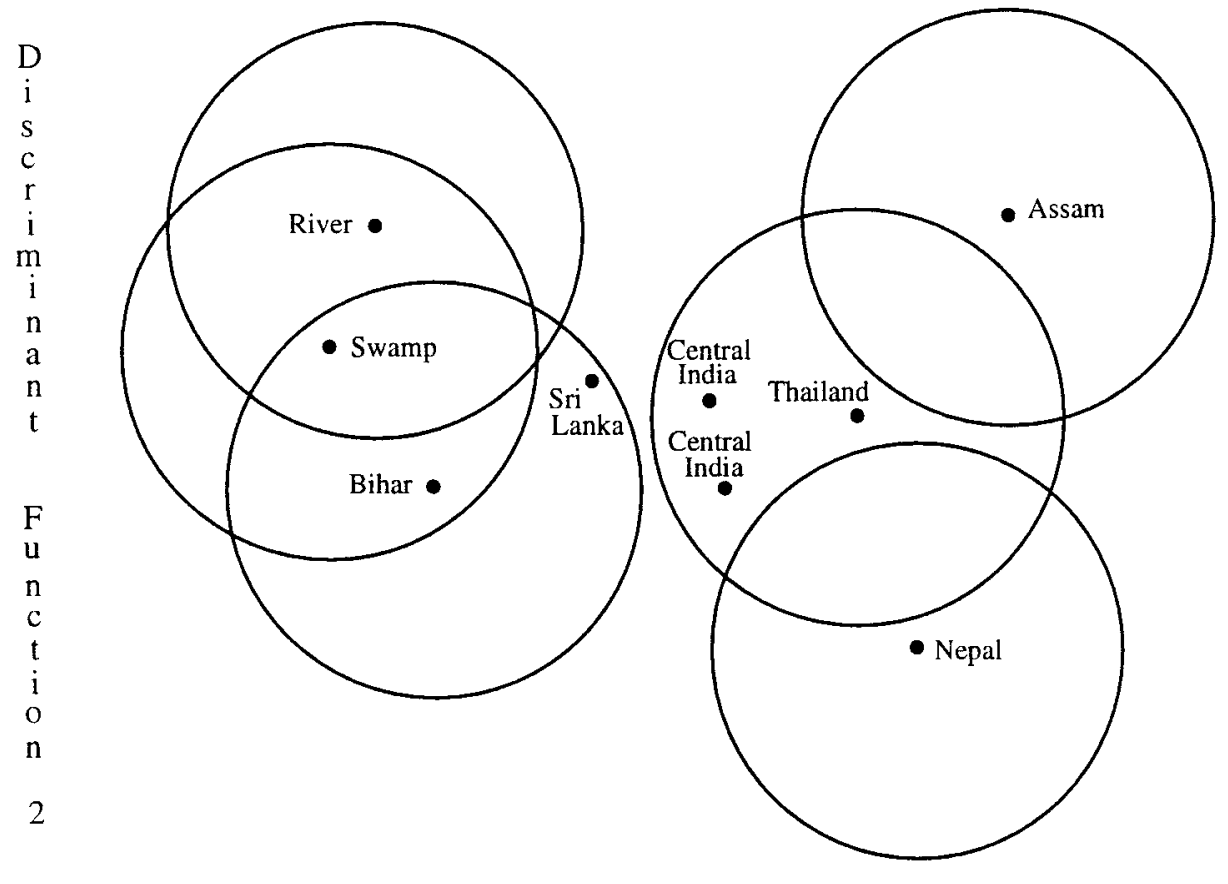

Discriminant Function 1

Figure 1. Discriminant analysis of cranial measurements in Asian buffaloes. The circles represent one-standard-deviation limits of samples from Assam,

Thailand, Nepal and Bihar/Orissa (wild) and swamp and river samples (domestic).

\section{Table-Sharers: Rodents of the Ricefields}

Groves (1984a) has surveyed a number of murid rodents that appear to have been introduced into Island Southeast Asia and are closely tied to wet rice landscapes. These animals are "commensal", meaning "sharing the same table", that is they live among humans and in their cultural landscape. Mus caroli, Mus cervicolor (Map 2) and Rattus argentiventer are widely distributed in Mainland Southeast Asia north of the Malay Peninsula; their distributions are spotty in the archipelago and invariably restricted to wet rice growing areas. If the pests travelled initially with the padi then a Burma/Thailand/Vietnam centre for the rice complex is suggested; if they came afterwards then a general importance for this area in later rice trading is indicated.

One species whose distribution does extend into the Mahanadi delta region, and so might have travelled with the water-buffalo from India, is the lesser bandicoot-rat, Bandicota bengalensis, a noted ricefield pest in Indonesia (Map 3). It is especially significant that, in Thailand, Indochina and most of Burma, 
The Austronesians: Historical and Comparative Perspectives

it is replaced by an ecologically equivalent species, B. savilei, which did not get introduced into the archipelago. 


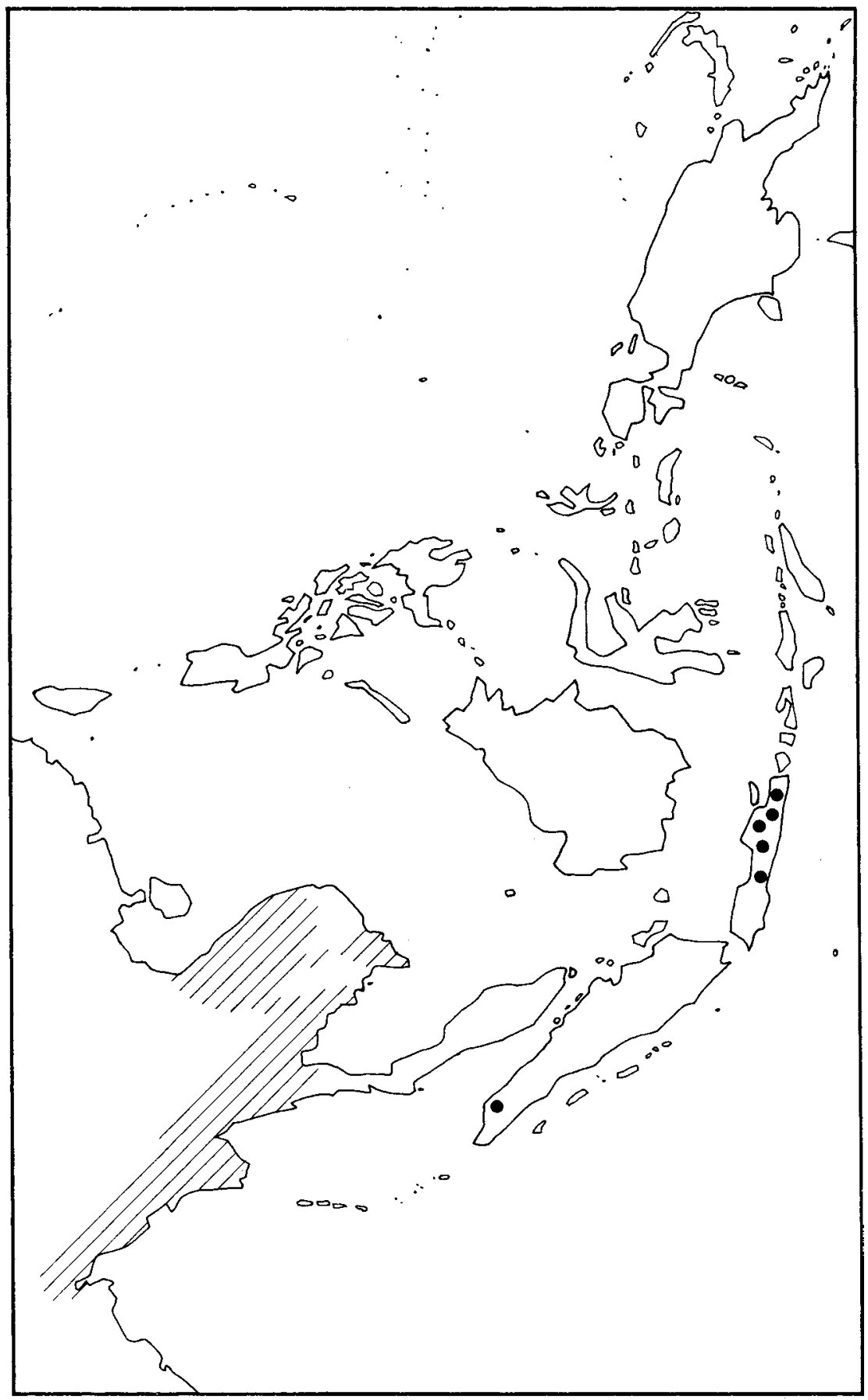

Map 2. Distribution of Mus cervicolor.

Solid dots represent approximate locations recorded. From Groves (1984b). 
The Austronesians: Historical and Comparative Perspectives

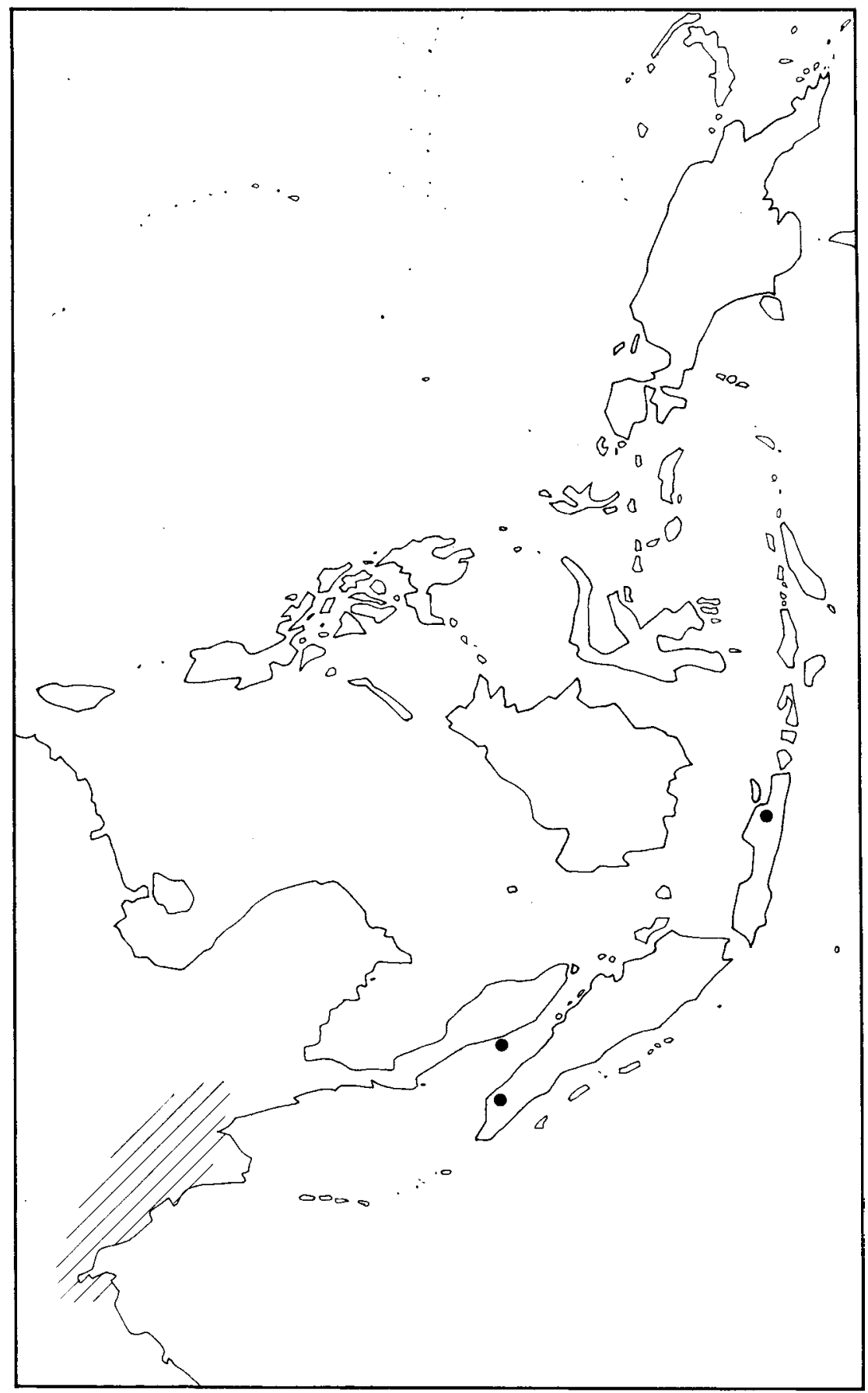

Map 3. Distribution of Bandicota bengalensis.

Diagonal lines indicate mainland distribution; solid dots recorded locations in Sundaland. From Groves (1984b). 
Two somewhat unexpected ricefield pests in Indonesia are Mus dunni, a small mouse indigenous to northwestern India, and Rattus nitidus, indigenous to Nepal. Surely no explanation to do with early rice expansion will suffice in these cases.

Finally, among the agricultural pests must be mentioned the Pacific rat, Rattus exulans, which is wild in both Mainland and Island Southeast Asia. Smaller than the worldwide commensal rats $R$. rattus (black rat, roof rat) and $R$. norvegicus (brown rat, ship rat, Norway rat), this was the only species occurring on the Pacific islands, where it was commonly eaten, in pre-European contact times. Unfortunately its very versatility precludes us from associating it with any particular subsistence mode.

\section{Local Contributions: Sapi and Babi}

\section{Cattle}

Despite their inferiority to buffaloes in a wet rice context, cattle can be similarly employed for ploughing, and Indonesia has even supplied a home-grown variety. This is the sapi Bali (Bali cow), a small type with white legs and white rump. Adult males are black with thick horns joined across the forehead by a cornified zone, and females, much smaller, are brown with simpler horns. Bali cattle are descended not from the same stock as other cattle, but from the banteng (Bos javanicus), a wild species still living in Southeast Asia. Banteng come in three subspecies:
Bos javanicus javanicus - Java
Bos javanicus lowi - Borneo
Bos javanicus birmanicus - mainland, north of the Malay Peninsula (it is one of the unexplained oddities of zoogeography that there are no banteng in Sumatra or Malaya south of Kedah).

Only the Java subspecies fulfils the criteria for an ancestor of Bali cattle; the other two are unlike them in characteristic ways. So the origin of Bali cattle must have been in Java (unless wild banteng at one time occurred in Bali as well: there is no evidence on this point).

Bali cattle are bred throughout Bali, but also in other areas of Indonesia such as Riau and Lampung in Sumatra, southeastern Borneo, east Java, south and southeast Sulawesi, and Timor (Rollinson 1984). In general, they are found wherever the introduced Indian humped cattle (zebu) are not found. We assume that, being inferior to these in size and so presumably in traction and beef yield, they have been widely replaced by them, though in some places (especially Bali itself) Bali cattle are protected by religious sentiment. Meijer (1962) mentions a depiction of a humped ox before a plough on the Borobudur, so the replacement 
had already begun by the ninth century AD. On the other hand, he records that Bali cattle were still being exported from Java in the 14th century.

\section{Pigs}

So to the pigs (Groves 1981, 1984a). An Indonesian species, Sus celebensis, indigenous to Sulawesi, still occurs today as a domesticate on Roti and Timor. It occurs wild on Timor, Flores, Halmahera and, unexpectedly, Simuleue (west of Sumatra). Such a bizarre distribution strongly suggests past human introduction - presumably in domestic form. On Halmahera, pigs of unknown species are present at c. 3500 BP (P. Bellwood, pers.comm.). Pigs descended from the species Sus scrofa, the widespread Eurasian wild pig, are today the domestic stock in most non-Muslim areas, but interspecies hybrids are the basis of the New Guinea pigs.

Even within S. scrofa there are informative divisions. Domestic and feral pigs of this species in Indonesia have the skull characters of S. scrofa vittatus, the wild pig of the region. Similar characteristics mark the pigs of the Andaman Islands, Flores, Admiralty Islands and Espiritu Santo (Vanuatu) as being of western Indonesian origin. On Tinian and Saipan, however, domestic and/or feral pigs occurred with the skull characteristics of wild Chinese (including Taiwanese) pigs. I am grateful to Robert Langdon for discussing these with me; they might be of rather recent origin, evidence for historic trade rather than ancient population movements. All these distributions are mapped in Map 4 (note that other species - Sus barbatus, S. verrucosus and the Philippine species - are not involved in domestication problems and are not mapped).

\section{Snappers-up of Unconsidered Trifles: Dogs and, Who Knows, Dingoes Too?}

Gollan (1985) found similarities between prehistoric dogs of the Indus Valley and the Australian dingo. Surely, one thought, not a direct connection jumping over Southeast Asia? Corbett (1985), however, was able to demonstrate that dingo-like dogs are widespread in Southeast Asia and studied the skulls of a series from Thailand, where apart from being pariah-like scavengers they are sold for food. The recency of the dingo's appearance in Australia makes sense if it was derived from an Austronesian pariah/table dog.

At the same time, there are both tame and feral dogs in the region which are not of dingo type: chiefly the New Guinea "singing dog" and the Tengger dog of eastern Java. It is tempting to see in these a relict of pre-Austronesian stocks, although there is no archaeological evidence either way. 


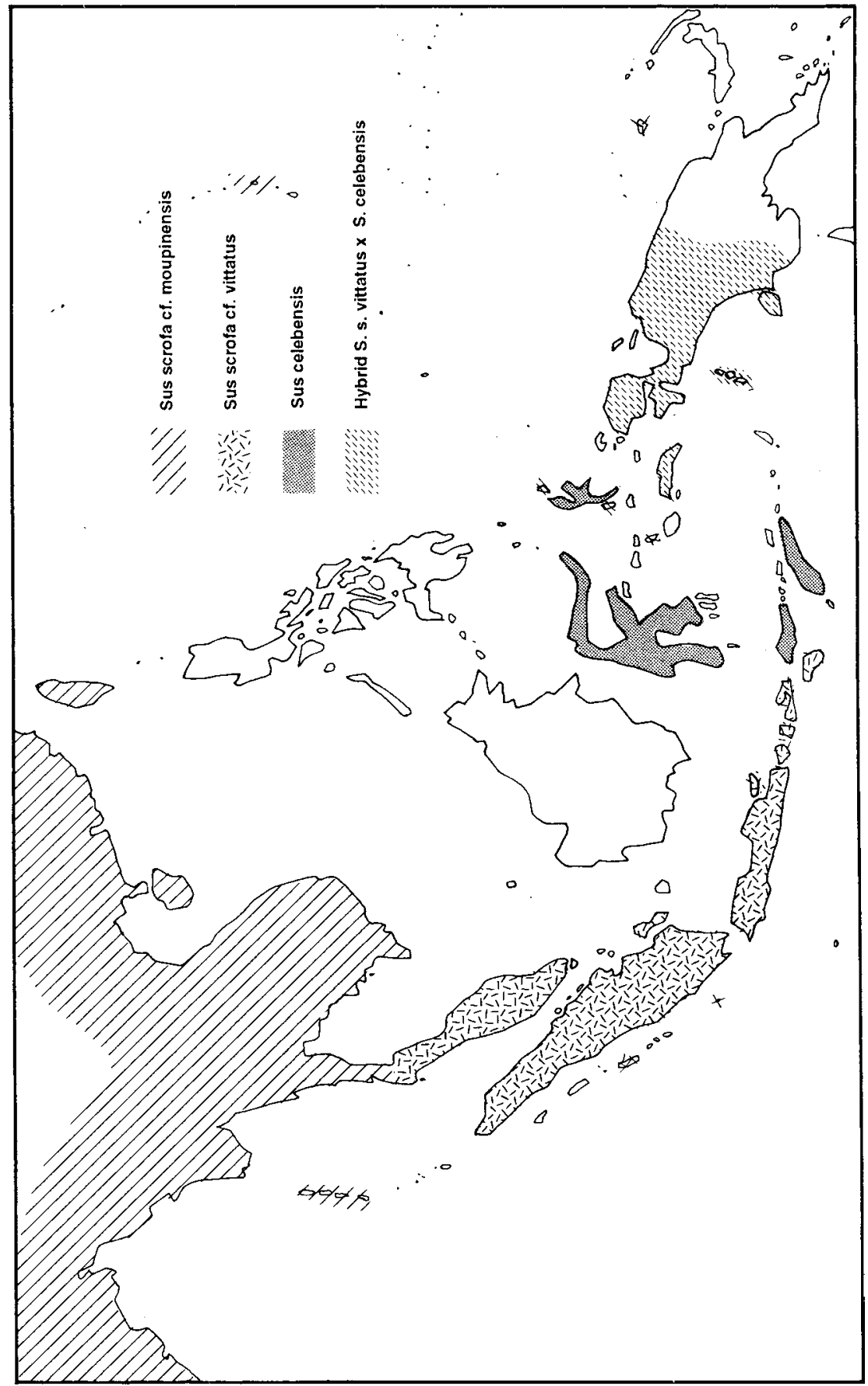

Map 4. Distribution of wild Sus scrofa, Sus celebensis and hybrids in Southeast Asia. From Groves (1984b). 


\section{In Conclusion}

The ancestral rice-growers of the Burma, Thailand and southern China regions evidently brought a suite of animals with them into Southeast Asia. Some were locals which had hitchhiked unbidden with the rice; others may have been grafted on via links with India. The buffalo was one of these and the dog may have been, but the pig was not - two different taxa of Sus were domesticated within Southeast Asia itself, as were Bali cattle. In the case of both pig and dog, Austronesian strains apparently replaced earlier strains which survive only as localized remnants.

Through the study of domestic and commensal mammals, particularly in the context of their ecological requirements, we can throw light on the spread of early human populations and their subsistence modes. The need now is to trace some of these same movements linguistically, again through the characteristic animals of the rice complex.

\section{References}

Corbet, G.B. and J. Clutton-Brock

1984 Taxonomy and nomenclature. In I.L. Mason (ed.) Evolution of domesticated animals, pp 434-438. London: Longman.

Corbett, L.K.

1985 Morphological comparisons of Australian and Thai dingoes: a reappraisal of dingo status, distribution and ancestry. Proceedings of the Ecological Society of Australia 13:277-291.

Gollan, K.

1985 Prehistoric dogs in Australia: an Indian origin? In V.N. Misra and P. Bellwood (eds) Recent advances in Indo-Pacific prehistory, pp.439-443. New Delhi: Oxford \& IBH Publishing Co.

Groves, C.P.

1981 Ancestors for the pigs. Technical Paper No. 3. Canberra: Department of Prehistory, Research School of Pacific Studies, The Australian National University.

1984a Pigs east of the Wallace line. Journal de la Société des Océanistes 39:105119.

1984b Of mice and men and pigs in the Indo-Australian archipelago. Canberra Anthropology 7:1-19.

Mason, I.L. 
1974a Species, types and breeds. In W. Ross Cockrill (ed.) The husbandry and health of the domestic buffalo, pp. 1-47. Rome: Food and Agricultural Organization.

1974b Genetics. In W. Ross Cockrill (ed.) The husbandry and health of the buffalo, pp.57-81. Rome: Food and Agricultural Organization.

Meijer, W.Ch.P.

1962 Das Balirind. Wittenberg Lutherstadt: Ziemsen Verlag (Die Neue BrehmBücherei).

Rollinson, D.H.L.

1984 Bali cattle. In I.L. Mason (ed.) Evolution of domesticated animals, pp.2834. London: Longman. 